\title{
Sizing Optimization of Grid-Connected Hybrid PV-Wind Energy Systems: State of Art Review and Perspectives
}

\author{
W. Ahouar ${ }^{1}$, L. Bousselamti ${ }^{1}$, M. Labbadi ${ }^{1}$, S. Lakrit ${ }^{2}$, M. Cherkaoui ${ }^{1}$ \\ ${ }^{1}$ Engineering for Smart and Sustainable Systems Research Center, Mohammadia School of Engineers, \\ Mohammed V University in Rabat, Morocco \\ ${ }^{2}$ Applied Mathematics and Information Systems Laboratory, EST of Nador, Mohammed First University, \\ Oujda, Morocco
}

(Received 10 January 2021; revised manuscript received 15 June 2021; published online 25 June 2021)

\begin{abstract}
Renewable energy systems are the major components of the strategy to reduce global warming. Hybrid systems using a combination of solar and wind energy are commonly used in remote areas; they have the advantage of reliability and stability. A hybrid energy system includes more than one energy source to cover an electrical load. Energy sources can be renewable as well as conventional. It can either be standalone or grid-connected. When a hybrid energy system includes solar or wind energy, it is important to add an auxiliary source of energy (coming from battery banks, diesel generator, or utility grid) so as to reduce energy cost and ensure system's reliability. Optimization sizing is one of the most important issues in this type of systems. In this regards much research has been done. The aim of this paper is to provide an overview of different criteria and methods utilized in current literature to find the optimal sizing of grid-connected hybrid PV-wind energy systems. This work concludes with promising techniques for future use in this field.
\end{abstract}

Keywords: Renewable energy, Hybrid PV-wind energy system, Grid-connected, Optimal sizing, State of art.

DOI: $10.21272 /$ jnep.13(3).03006

PACS number: $84.60 .-\mathrm{h}$

\section{INTRODUCTION}

\subsection{Motivation}

Hybrid system can be configured in stand-alone or grid-connected mode. It depends on the grid availability, the cost of grid-supplied electricity, etc.

For the grid-connected hybrid systems, there is two options; the first is that the system may supply the local needs and fed any surplus, first to the storage (if there is), then to the grid. The second is when the hybrid system is managed by the utilities like a power plant and it fed all energy produced to the utility grid. A gridconnected hybrid PV-wind energy system presents a strategic value for electricity networks in the future; the power provided by the system during off-peak periods can be stored and released at on-peak times.

Stand-alone systems are independent from the grid, as a result, they need extra storage and auxiliary energy (diesel generator).

\subsection{Related Works}

In the literature, we find a number of review papers on hybrid PV-wind energy systems. Moreover, there is a lot of studies dedicated to sizing optimization of stand-alone PV-wind hybrid energy systems but there are few studies that focus on grid-connected PV-wind systems sizing; In the reference [1] a methodology for finding the sizing that leads to the mini-mum life cycle cost of the hybrid grid-connected PV and wind power system was presented. In [2], the environmental and economic impacts was taking into account to make a comparison between a grid-connected PV-wind energy system and a standard grid operation. The PV-wind system was considered as a grid power generation.

The work developed in [3] was a method for the business optimal design of a small grid-connected hyThe results were presented at the International Conference on Innovath brid energy system, the objective was to minimize the LCC (Life Cycle Cost) of the system while ensuring a level of system reliability. The authors of [4] analyzed the influence of some sizing parameters on the interaction of the grid-connected hybrid wind-photovoltaic systems with the grid. It can be observed that the mentioned works did not address all the constraints that this kind of systems presents.

\subsection{Contribution}

This work presents a state of art review of gridconnected PV-wind hybrid energy systems sizing optimization criteria and techniques and gives future research directions.

\subsection{Paper Organization}

The paper organization is as follows. Section 2 gives the meteorological data generation methods. Evaluation criteria and optimization methods applied to hybrid PVwind systems sizing are presented in sections 3 and 4 , respectively. Section 5 presents promising techniques for future use and section 6 gives some future prospects. Finally, a conclusion with perspectives is given.

\section{METEOROLOGICAL DATA GENERATION}

Weather data contains hourly solar radiation, wind speed and ambient temperature. Some researchers use global meteorological data, the source can be a local station or that could be obtained from internet. When the weather data do not exist for a location, they can be synthetically generated from the monthly values, or they can be extrapolated from a nearby location. Typical meteorological year is one of the most synthetic weather data used in hybrid energy designing. Each month is selected as the best representative of that particular vative Research in Renewable Energy Technologies (IRRET-2021) 
month. Based on statistical meteorological data, various studies are done to evaluate the performance of hybrid PV-wind energy systems [5].

\section{EVALUATION CRITERIA FOR HYBRID PV-WIND SYSTEM OPTIMIZATION}

\subsection{Power Reliability}

The power reliability analysis is an important criteria in the design process, the most popular method to calculate the reliability of hybrid systems is the Loss of Power Supply Probability (LPSP) [6]. It is defined as the ratio of energy deficit to the total demand during a period. There are other power reliability criteria such as:

1. Loss of Load Expected (LOLE); it is the energy that will not be supplied when load exceeds generation, the System Performance Level (SPL) [7].

2. The Total Energy Lost (TEL) due to extra generated power (it is sold to the grid according to the adopted system energy management strategy [8]).

3. Level of autonomy (LA); it is defined as the ratio of the total number of hours in which loss of load (LOL) occurs to the total hours of operation [9].

4. State of charge (SOC) in the batteries; it can help to select a storage capacity ensuring the constraints must be satisfied [10].

\subsection{Economic Criteria}

The economic criteria helps to select from several hybrid configurations, the one with the lowest cost, the present component cost is generally given for an identified year and the capital recovery factor (CRF) [11] allows converting this cost into an annual cost.

In the literature, many economic criteria are used:

1. Levelized Cost of Energy (LCE/LCOE) or Levelized Energy Cost (LEC); it is defined as the ratio of the total yearly cost of the system and the yearly energy produced by the system (or consumed by the load) over the lifetime of the system [12].

2. Net Present Value (NPV), Net Present Cost (NPC) or Total System Cost (TSC) which is an estimation of the total cost of the system including investment, maintenance, operation and replacement through the useful lifetime [13].

3. Annualized cost of system (ACS); it is a summation of various annual costs such as the annualized capital, annualized maintenance and the annualized replacement costs [14].

\subsection{Environmental Criteria}

The environmental parameter has become more and more important in the last decade. Reducing pollutant emissions is taking as an objective in the hybrid energy systems design.

The indicators used are:

1. The emissions of $\mathrm{NO}_{x}, \mathrm{CO}_{2}$ and $\mathrm{SO}_{2}$ produced by the system during a period of time [8].

2. $\mathrm{CO}_{2}$ mitigation, which is the quantity of $\mathrm{CO}_{2}$ emissions mitigated by using the hybrid energy system [15].

3. Embodied Energy (EE); it is the primary energy required for components manufacturing process [16].

\section{OPTIMIZATION METHODS APPLIED TO HYBRID PV-WIND ENERGY SYSTEM SIZING}

\subsection{Commercially Tools for Hybrid PV-wind Energy System Simulation and Optimization}

There are many software applications for sizing hybrid PV-wind energy systems. A non-exhaustive list of those software tools is presented in Table 1.

Table 1 - Software tools for sizing hybrid PV-wind energy systems

\begin{tabular}{|l|l|}
\hline Software tools & \multicolumn{1}{c|}{ Outputs } \\
\hline HOMER & $\begin{array}{l}\text { Optimal sizing } \\
\text { Cost of energy net present cost }\end{array}$ \\
\hline HYBRID2 & $\begin{array}{l}\text { Unit sizing with cost optimization } \\
\text { Cost of energy } \\
\text { Percentage of various greenhouse } \\
\text { gases }\end{array}$ \\
\hline HYBRIDS & $\begin{array}{l}\text { Cost of energy } \\
\text { Emission percentage of various } \\
\text { greenhouse gases }\end{array}$ \\
\hline IHOGA & $\begin{array}{l}\text { Multi-objective optimization } \\
\text { Cost of energy } \\
\text { Life cycle emission }\end{array}$ \\
\hline
\end{tabular}

\subsection{Optimization Techniques Utilized in Literature for Hybrid PV-Wind Energy System Sizing}

\subsubsection{Graphic Techniques}

A number of studies have been used graphical construction method. The paper [17] presented a graphic technique for finding optimum size of a PV-wind hybrid system, the optimum configuration was calculated, for a given load and a desired LPSP, based on the minimum cost of the system. Various factors (PV module slope angle and wind turbine installation cost) were not included in this study.

\subsubsection{Probabilistic Techniques}

Probabilistic approach considers the effect of random variability of parameters. The paper [18] presents a Monte-Carlo simulation method that provides objective indicators to help system planners. A convolution method is presented in reference [19] which takes into consideration a penetration level selected by the utility. The probabilistic technique is used to solve hybrid system sizing problem. Other examples are available. However, it cannot represent the dynamic changing performance of the system, which is main limitation.

\subsubsection{Analytical Techniques}

Hybrid energy systems in these techniques are represented by means of computational models, which describe the hybrid system size as a function of its feasibility. It require less time than Monte-Carlo to obtain the required size for a definite demand [20]. Reference [21] used discrete Fourier transform to decompose balancing power into different time-varying periodic components. 


\subsubsection{Iterative Technique}

Paper [22] presents an algorithm developed for standalone and grid connected mode where an energy filter is applied to smooth out the fluctuation of power injected in to the grid. Iterative optimization technique requires more computational efforts and usually some parameters are not optimized in most of studies available in literature.

\subsubsection{Artificial Intelligence Techniques}

Genetic Algorithm (GA); is an algorithm inspired by natural evolution, it can solve problems with multiple solutions, a number of references have used the GA for optimizing the design of PV-wind systems. [23] proposed an optimal sizing of a PV-wind-diesel-battery system using GA. The decision variables were the PV array capacity, wind turbine number, battery bank number and diesel generator rated power.

Particle Swarm Optimization (PSO); inspired by bird and fish movement behavior. Reference [24] used a particle swarm optimization for energy management strategy, as a conclusion, it is funded that the PSO technique has fast convergence time com-pared to sequential quadratic programming.

Simulated Annealing (SA); which is inspired by material annealing processing, it is a robust technique used in optimal sizing of energy systems. The paper [25] used a SA algorithm for sizing a PV-wind-battery system. The decision variables were PV size, wind turbine rotor swept area and the battery capacity.

\subsubsection{Hybrid Techniques}

Hybrid techniques combine two or more different methods. Since most of the sizing problems have multiobjective nature, implementation of hybrid method is the best solution. However, these a deep understanding of all the techniques is needed.

In [26], authors presented a hybrid simulated annealing-tabu search (SA-TS) which improves the quality and convergence of the solutions, compared to the those provided by an individual SA or individual TS methods.

Table 2 - Optimization techniques utilized for hybrid PVwind energy systems sizing and their limitations

\begin{tabular}{|l|l|}
\hline \multicolumn{1}{|c|}{$\begin{array}{c}\text { Optimization } \\
\text { techniques }\end{array}$} & \multicolumn{1}{c|}{ Limitation } \\
\hline Graphic techniques & $\begin{array}{l}\text { Some parameters (PV module } \\
\text { slope angle and the wind tur- } \\
\text { bine installation height) are } \\
\text { not taken into account in the } \\
\text { optimization }\end{array}$ \\
\hline $\begin{array}{l}\text { Probabilistic } \\
\text { techniques }\end{array}$ & $\begin{array}{l}\text { Unable to represent the dy- } \\
\text { namic performance of the } \\
\text { hybrid energy system }\end{array}$ \\
\hline $\begin{array}{l}\text { Analytical } \\
\text { techniques }\end{array}$ & $\begin{array}{l}\text { Less flexible in designing of } \\
\text { the system }\end{array}$ \\
\hline Iterative techniques & $\begin{array}{l}\text { Some parameters are not } \\
\text { optimized }\end{array}$ \\
\hline $\begin{array}{l}\text { Artificial intelligence } \\
\text { techniques }\end{array}$ & Complex solving process \\
\hline Hybrid techniques & Complex solving process \\
\hline
\end{tabular}

From what is above and Table 2, it can be concluded that artificial intelligence and hybrid techniques provide the maximum flexibility among the other sizing optimization techniques.

\section{PROMISING TECHNIQUES FOR FUTURE USE IN GRID-CONNECTED HYBRID PV-WIND ENERGY}

Several artificial intelligence techniques inspired by nature are formulated recently. Some of these techniques can be used in optimizing grid connected hybrid PV-wind size.

\subsection{Ant Colony Algorithm (ACA)}

Ant colony algorithm is inspired by foraging behavior of ant colonies. It has success-fully used in many optimization problems. In [27], a PV-wind system design was optimized using ant colony algorithm, the objective function was the total design cost.

\subsection{Artificial Bee Colony Algorithm (ABC)}

$\mathrm{ABC}$ is a metaheuristic algorithm based on the intelligent foraging behaviors of honey bees. [28] used $\mathrm{ABC}$ algorithm to optimally size a hybrid energy system based on PV panels, wind turbines and fuel cell. The objective function was the total annual cost. The maximum allowable loss of power supply probability (LPSPmax) was also considered.

\subsection{Harmony Search Algorithm (HAS)}

Harmony search algorithm is one of populationbased optimization algorithm that is used with a variety of meta-heuristic optimization techniques. In [29], the Harmony Search, Jaya and Particle Swarm optimization algorithms are used in order to size a windPhotovoltaic-Biomass-Battery hybrid energy system with the objective of cost-effectively, efficiently and reliably meeting the electricity demand. There are many others optimization techniques that seem promising to face complexity of PV-wind hybrid systems. The selection of the suitable method depends on the type of inputs parameters, objective functions and constraints.

\section{FUTURE PROSPECTS}

The techniques mentioned in the previous section are increasingly used in hybrid energy systems sizing. Therefore, it is recommended to use them in gridconnected PV-wind energy systems, they may provide promising optimal sizes. Little research considers the environmental impact in sizing optimization problems for grid-connected hybrid energy systems. Therefore, it should be given more attention in the future. In gridconnected PV-wind energy systems there are several issues related to the interaction with the grid such as electricity prices fluctuating and grid codes requirements, these issues can be addressed in future research.

\section{CONCLUSIONS}

From this state of art review, it can be observed that hybrid PV-wind energy is a good option to integrate 
alternative energy sources in the process of electrical power generation. In the majority of the available works related to grid-connected PV-wind, the objective design functions are the cost and the reliability of the system. However, for this type of systems, too many aspects are to be taking into consideration such as reducing harmful emissions, electricity prices fluctuating and grid codes requirements. Future research can be about application of evolutionary algorithms for a multi-objective optimization of grid-connected hybrid PV-wind energy systems.

\title{
REFERENCES
}

1. A. González, J.-R. Riba, A. Rius, R. Puig, Appl. Energ. 154, 752 (2015)

2. J.L. Bernal-Agustín, R. Dufo-López, Renew. Energy 35, 747 (2010).

3. F. Caballero, E. Sauma, F. Yanine, Energy 61, 248 (2013).

4. Á.A. Bayod-Rújula, M.E. Haro-Larrodé, A. Martínez-Gracia, Sol. Energy 98, 582 (2013).

5. M.A. Elhadidy, Renew. Energy 26, 401 (2002).

6. S. Diaf, G. Notton, M. Belhamel, M. Haddadi, A. Louche, Appl. Energy 85, 968 (2008).

7. M. Fan, V. Vittal, G.T. Heydt, R. Ayyanar, IEEE Trans. Power Syst. 27, 2251 (2012).

8. M. Alsayed, M. Cacciato, G. Scarcella, G. Scelba, IEEE Trans. Energ. Convers. 28, 370 (2013).

9. A.N. Celik, Energ. Convers. Manag. 44, 1951 (2003).

10. H.X. Yang, L. Lu, J. Burnett, Renew. Energy 28, 1813 (2003).

11. A.T.D. Perera, R.A. Attalage, K. Perera, V.P.C. Dassanayake, Energy 54, 220 (2013).

12. A. Askarzadeh, L. dos Santos Coelho, Sol. Energy 112, 383 (2015).

13. R. Dufo-López, J.L. Bernal-Agustín, F. Mendoza, Energy Polic. 37, 3082 (2009).

14. H. Yang, Z. Wei, L. Chengzhi, Appl. Energy 86, 163 (2009).

15. K. Anoune, A. Laknizi, M. Bouya, A. Astito, A. Ben Abdellah, Energy Convers. Manag. 169, 137 (2018).

16. D. Abbes, A. Martinez, G. Champenois, Math. Comp. Simul. 98, 46 (2014)

17. B.S. Borowy, Z.M. Salameh, IEEE Trans. Energy Convers. 11, 367 (1996)

18. R. Karki, R. Billinton, IEEE Trans. Energy Convers. 16, 368 (2001).

19. S.H. Karaki, R.B. Chedid, R. Ramadan, IEEE Trans. Energy Convers. 15, 284 (2000).

20. D.K. Khatod, V. Pant, J. Sharma, IEEE Trans. Energ. Convers. 25, 535 (2010).

21. Y.V. Makarov, P. Du, M.C. Kintner-Meyer, C. Jin, H.F. Illian, IEEE Trans. Sustain. Energy 3, 34 (2012).

22. L. Xu, X. Ruan, C. Mao, B. Zhang, Y. Luo, IEEE Trans. Sustain. Energy 4, 774 (2013).

23. A.A. Al-Shamma'a, K.E. Addoweesh, 2012 IEEE Int. Conf. on Power and Energy (PECon), 121 (IEEE: 2012).

24. S.A. Pourmousavi, M.H. Nehrir, C.M. Colson, C. Wang, IEEE Trans. Sustain. Energy 1, 193 (2010).

25. O. Ekren, B.Y. Ekren, Appl. Energy 87, 592 (2010).

26. Y.A. Katsigiannis, P.S. Georgilakis, E.S. Karapidakis, IEEE Trans. Sustain. Energy 3, 330 (2012).

27. A. Fetanat, E. Khorasaninejad, Appl. Soft Comp. 31, 196 (2015)

28. A. Maleki, A. Askarzadeh, Sol. Energy 107, 227 (2014).

29. N. Alshammari, J. Asumadu, Sustain. Cities Soc. 60, 102255 (2020).

\section{Оптимізація розмірів гібридних енергетичних систем, підключених до мережі: сучасний рівень розвитку та перспективи}

\author{
W. Ahouar ${ }^{1}$, L. Bousselamti ${ }^{1}$, M. Labbadi ${ }^{1}$, S. Lakrit ${ }^{2}$, M. Cherkaoui ${ }^{1}$ \\ ${ }^{1}$ Engineering for Smart and Sustainable Systems Research Center, Mohammadia School of Engineers, \\ Mohammed V University in Rabat, Morocco \\ ${ }^{2}$ Applied Mathematics and Information Systems Laboratory, EST of Nador, Mohammed First University, \\ Oujda, Morocco
}

\begin{abstract}
Системи поновлюваних джерел енергії є основними компонентами стратегії зменшення глобального потепління. Гібридні системи, що використовують комбінацію сонячної енергії і енергії вітру, зазвичай використовуються у віддалених районах, їх перевагами є надійність і стабільність. Гібридна енергетична система включае більше одного джерела енергії для покриття електричного навантаження. Джерела енергії можуть бути як поновлюваними, так і традиційними. Вони можуть бути автономними або підключеними до мережі. Коли гібридна енергетична система використовуе сонячну енергію або енергію вітру, важливо додати допоміжне джерело енергії (акумуляторні батареї, дизельний генератор або комунальна мережа), щоб знизити вартість енергії і забезпечити надійність системи. Оптимізація розмірів - одна з найважливіших проблем в системах такого типу. У зв'язку з цим було проведено багато досліджень. Метою роботи є аналіз різних критеріїв та методів, що використовуються в сучасній літературі для пошуку оптимального розміру підключених до мережі гібридних систем. Робота завершуеться оглядом перспективних методів для подальшого використання у цій галузі.
\end{abstract}

Ключові слова: Відновлювана енергія, Гібридна система, Підключений до мережі, Оптимальні розміри, Сучасний рівень розвитку. 